\title{
A Note on (Dis)Investment Options and Perpetuities Under CIR Interest Rates
}

\author{
Manuela Larguinho, José Carlos Dias, and Carlos A. Braumann
}

\begin{abstract}
In this chapter, we discuss alternative ways of computing the options to invest in and divest from an investment project in a CIR economy (Cox et al., Econometrica 53(2):385-408, 1985). Moreover, different methods of determining CIR perpetuities will also be analyzed.
\end{abstract}

\section{Introduction}

The most realistic case of the capital theory of investment is characterized by investments with costly reversibility in which a firm can purchase capital at a given price (by paying an investment $\operatorname{cost} \bar{I}$ ) and sell capital at a lower price (by receiving the divestment proceeds $\underline{I}$ ), i.e., there is a fraction $\alpha$ of the invested capital, $\alpha:=\underline{I} / \bar{I}$ $(0<\alpha<1)$, that a firm can recoup when divesting.

Decisions made under an uncertain environment where it is costly to reverse economic actions lead to an intermediate range, called the hysteretic band, where the continuation is the optimal policy until some threshold is reached.

M. Larguinho $(\square)$

Department of Mathematics, ISCAC, Quinta Agrícola, Bencanta, 3040-316 Coimbra, Portugal e-mail: mlarguinho@iscac.pt

J.C. Dias

BRU-UNIDE and ISCTE-IUL Business School, Av. Prof. Aníbal Bettencourt,

1600-189 Lisboa, Portugal

e-mail: jose.carlos.dias@iscte.pt

C.A. Braumann

Department of Mathematics, Centro de Investigação em Matemática e Aplicações, Universidade de Évora, Rua Romão Ramalho 59, 7000-671 Évora, Portugal

e-mail: braumann@uevora.pt

P.E. Oliveira et al. (eds.), Recent Developments in Modeling and Applications

203 in Statistics, Studies in Theoretical and Applied Statistics,

DOI 10.1007/978-3-642-32419-2_21, () Springer-Verlag Berlin Heidelberg 2013 